\title{
Subject specific pedagogy based on discovery learning and volcanic eruption disasters: Does it affect students' concept mastery?
}

\author{
Rizki Arumning Tyas $^{1^{*}}$, Pujianto ${ }^{2}$, Suyanta $^{3}$ \\ ${ }^{1,2,3}$ Graduate School of Yogyakarta State University, Jl. Colombo No 1, Yogyakarta, Indonesia \\ *Corresponding Address: rizki.arumningtyas@gmail.com
}

\begin{tabular}{|c|c|}
\hline Article Info & ABSTRACT \\
\hline$A r$ & \multirow{5}{*}{$\begin{array}{l}\text { This study aimed to determine the effect of science Subject Specific } \\
\text { Pedagogy Based on Discovery Learning and Volcanic Eruption Disasters on } \\
\text { students' concept mastery. This research was a quasi-experiment study with } \\
\text { two sample groups, the experimental and the control classes of SMP N } 2 \\
\text { Cangkringan. The instrument to collect the concept mastery data were } 35 \\
\text { items. The data were analyzed using descriptive and inferential analysis. The } \\
\text { descriptive analysis employed the categorization of the gain score while the } \\
\text { inferential analysis employed the independent sample t-test and effect size } \\
\text { test using Partial Etta Square. The results showed that there was an effect of } \\
\text { the science subject-specific pedagogy based on discovery learning and } \\
\text { volcanic eruption disaster on student's concept mastery with a gain score of } \\
0.79 \text { (high) in the experimental class while the control class obtained } 0.07 \\
\text { (low). The independent sample t-test showed that the significance value } \\
\text { obtained was 0,000. The effect size value seen from the Partial Etta Square } \\
\text { statistics was 0.924, which showed that the effect of the science Subject } \\
\text { Specific Pedagogy Based on Discovery Learning and Volcanic Eruption } \\
\text { Disasters on the concept mastery is very strong. Thus, it can be concluded } \\
\text { that the use of science Subject Specific Pedagogy Based on Discovery } \\
\text { Learning and Volcanic Eruption Disasters can increase the student's science } \\
\text { concept mastery. Further integration and development can be done for other } \\
\text { types of disasters because it is one of the nature symptoms that also an } \\
\text { object of natural science. Thus, natural science learning will be more } \\
\text { meaningful because it is attached to the phenomena in the students' daily } \\
\text { lives. }\end{array}$} \\
\hline $\begin{array}{l}\text { Received: July } 14^{\text {th }}, 2020 \\
\text { Accepted: October } 22^{\text {nd }}, 2020\end{array}$ & \\
\hline & \\
\hline Keywords: & \\
\hline $\begin{array}{l}\text { Concept mastery; } \\
\text { Discovery learning; } \\
\text { Science SSP; } \\
\text { Volcanic eruption. }\end{array}$ & \\
\hline
\end{tabular}

(c) 2020 Physics Education Department, UIN Raden Intan Lampung, Indonesia.

\section{INTRODUCTION}

Integrated natural science learning in junior high school requires teaching materials to support learning activities. Subject Specific Pedagogy (SSP) is required to support integrated natural science learning, facilitating natural science learning in an integrated way. Thus, students can understand natural science comprehensively (Syaban \& Wilujeng, 2016). One of the steps that can be taken is to combine science learning by integrating essential competencies, forming a theme, and then reviewing the theme according to physics, chemistry, and biology.

SSP includes competency standards, materials, strategies, methods, media, and learning outcome scoring instruments (Prasetyo, 2011). In the preparation of SSP, the components combined are the teacher's knowledge of the subjects, the teacher's knowledge of the learner's condition, the teacher's knowledge of the curriculum, and the teacher's knowledge of instructional strategies. The four components are known 
as Pedagogical Content Knowledge (Hartati, 2016).

Science SSP is presented in various methods, strategies, and learning models set out in the syllabus and translated into a lesson plan to achieve the expected competency. One of the models that often used is discovery learning. Students are directed to understand that is to be achieved independently by teachers' guidance and supervision (Mukti et al., 2020; Puspitasari \& Handziko, 2018).

Learning science is not just about memorizing concepts. However, students are trying to find concepts so that in their learning, the teacher transfers their knowledge informatively and invites the learners to engage directly. Based on the interview results with the natural science teacher in SMP N 2 Cangkringan, students' concept mastery is still low. That condition force teachers to conduct learning activities through notes and lectures.

Natural Science teaches natural phenomena and symptoms that often occur in daily life. One example of a natural phenomenon in natural science is volcanic eruptions. Riezqia et al. (2017), Setiawan et al. (2017), and Tyas et al. (2020) mention that natural science learning integrated with a phenomenon or something close to the students' daily life will make them easier to master and understand the concept of learning.

As a country located in the Pacific Ring of Fire, Indonesia has 129 active volcanoes, which have the world's highest potential for volcanic disaster or eruption (Verstappen, 2013). Volcanic eruptions have an impact on the community as well as the public facilities that exist nearby. The high risk of disaster is due to the lack of knowledge and understanding of the community related to the volcano and its dangers (Amri et al., 2016). This resulted in high financing for the evacuation of natural disaster victims (Kenny, 2012). If disaster management can be focused on efforts before a disaster occurs, the budget allocated for natural disaster victims' evacuation can be diverted for other purposes.

The high risk of disaster should be directly proportioned to the level of awareness of the population. However, not all residents in the volcano area understand what to do when the volcano eruption occurs. Indonesia is the fifth largest population country globally. However, its people's knowledge and attitude have not been able to reflect the behavior of people who are prepared for disaster (Hidayati, 2012). Efforts are needed to avoid more significant impacts, both on the development of infrastructure, facilities, or human resources in affected areas. One of the efforts that can be done is to provide knowledge and information through formal education in schools (Sadeka et al., 2020; Sangkala \& Gerdtz, 2018).

Based on interviews with natural science teachers at SMP N 2 Cangkringan and students' final test analysis, students' cognitive level was low. This forced teachers to focus on the mastery of cognitive aspects only. The situation also forced the teachers not to be free to explore various learning models. Students had never been invited to do practical activities. Belton (2016) states that practice activities can improve students' skills.

Based on the interview results, it was also known that the integration of disaster learning has not been implemented. This was because teachers encountered problems in the preparation of learning devices. These constraints were related to limited references. During this time, teachers used learning devices adopted from the Sleman District Teacher Deliberation forum.

Almukarramah et al. (2013) and Hayudityas (2020) mentioned that the ultimate goal of the integration of disaster education in learning is students who are prepared to deal with disasters. Preparedness can be achieved if students have mastered the concept of learning (Tahmidaten \& Krismanto, 2019; Widjanarko \& Minnafiah, 2018). 
Today, integrated learning with disaster education is limited to the development of natural disaster integrated learning media, as in research conducted by Labibah et al. (2019), which develops android based learning media integrated with landslide disaster. Moreover, Setiawati et al (2013) also developed a natural science storybook integrated disaster material that effectively improves students' reading and character formation literacy.

A good SSP is an SSP that facilitates learning with content knowledge, pedagogical knowledge, and technological knowledge (Lee \& Kim, 2014; Lin et al., 2013). Interactions between content, pedagogy, and technology provide complex knowledge (Koehler \& Mishra, 2009). The right combination of learning and storybook packaged in SSP, supported by curriculum study and proper learning model, can be a whole SSP unit that facilitates integrated learning of natural disasters with science education in junior high school.

The existing development of Science SSP is still limited. Existing Science SSP is mostly integrated with local potential packaged with specific learning models and approaches (Kusmawati, 2017; Perkasa \& Aznam, 2016). The integration of natural science learning is also done with health sciences (Arnold, 2018). Besides that, Yahaya et al. (2016) also conduct science learning with sexually themed science content. Turkka et al. (2017) integrating natural science learning with art, while, Guzey \& Ring-whalen (2018) integrate engineering values into science learning. These variations of natural science learning integration show good results. Besides acquiring science knowledge, students also acquire other knowledge to enrich their knowledge.

Based on this, the existence of Science SSP integrated natural disasters is still minimal. This research aimed to determine the effect of Science SSP based on discovery integrated volcanic eruption disaster learning to the student's concept mastery. This discovery learning Science SSP consists of six syntaxes: stimulation stage, problem statement stage, data collection, data procession, verification, and generalization (Djamarah \& Zain, 2013; Hanafi, 2016; Syah, 2013). The Discovery learning model was chosen because the syntax was able to facilitate the learning. Students undergo learning by following the syntax. A disaster approach characterizes each syntax. Besides, many studies found discovery learning success to improve students' conceptual and procedural knowledge (Großmann \& Wilde, 2019). Schijndel et al. (2018) also found that discovery learning models support students' curiosity. This supports the selection of discovery learning models in this study, but some adjustments are still related to disaster integration.

\section{METHODS}

This research was a quasi-experiment using two groups with specific treatments. This research design was a pretest-posttest equivalent control group design (Sugiyono, 2015). The subjects cannot be randomized because it was not possible to obtain permission from the school to change classes. However, it can be anticipated by ensuring that each subject group is a heterogeneous group of individuals (Afriana et al., 2016; Anazifa \& Djukri, 2017; Hairida, 2016).

There were two groups given the treatment of a pre-test to find out the initial condition (Azwar, 2015). After that, the experimental group was treated using the Science SSP based on discovery learning and volcanic eruptions while the control class was treated with Science SSP with a scientific learning model. A post-test was carried out to determine the final state after treatment. The flow chart of the research procedures, as described in Figure 1. 


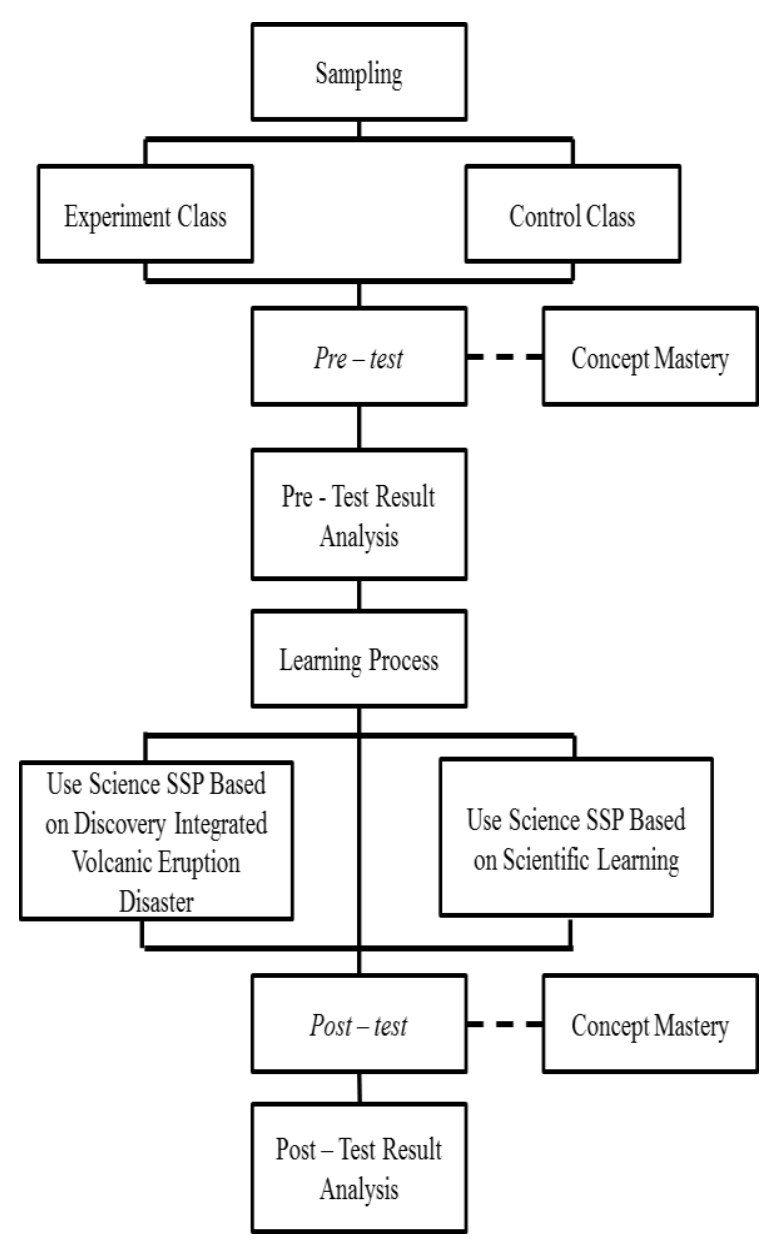

Figure 1. Research procedure flowchart

The research was conducted at SMP N 2 Cangkringan due to the school located in the disaster-prone area of Merapi Mountain, Yogyakarta. This study sample was 30 experiment class students and 30 control class students selected using purposive sampling techniques. The consideration was from the teachers, that mention students' ability in both classes is almost the same, judging by daily replays and the final assessment results.

The concept mastery data collection instrument uses a concept mastery assessment question consisting of 35 questions that have previously undergone a validation process, both constructs and empirical. The question is valid and reliable. The grid of questions as shown in Table 1.
Table 1. The competence assessment instrument

\begin{tabular}{|c|c|}
\hline $\begin{array}{c}\text { Indicators of Competency } \\
\text { Achievement }\end{array}$ & $\begin{array}{l}\text { Number } \\
\text { of Items }\end{array}$ \\
\hline $\begin{array}{l}\text { Students can explain the structure of } \\
\text { the earth }\end{array}$ & 4 \\
\hline $\begin{array}{l}\text { Students can explain the theory of } \\
\text { plate shift }\end{array}$ & 4 \\
\hline $\begin{array}{l}\text { Students can explain the processes of } \\
\text { volcanic formation }\end{array}$ & 4 \\
\hline $\begin{array}{l}\text { Students can explain the } \\
\text { characteristics of volcanoes }\end{array}$ & 4 \\
\hline $\begin{array}{l}\text { Students can describe the signs of a } \\
\text { volcanic eruption }\end{array}$ & 4 \\
\hline $\begin{array}{l}\text { Students can sort the stages of the } \\
\text { volcanic eruption }\end{array}$ & 3 \\
\hline $\begin{array}{l}\text { Students can explain efforts to reduce } \\
\text { the risk of volcanic eruption disaster }\end{array}$ & 4 \\
\hline $\begin{array}{l}\text { Students can classify the impact of } \\
\text { volcanic eruptions on the biotic } \\
\text { ecosystem }\end{array}$ & 4 \\
\hline $\begin{array}{l}\text { Students can classify the impact of } \\
\text { volcanic eruptions on the abiotic } \\
\text { ecosystem }\end{array}$ & 4 \\
\hline
\end{tabular}

Data analysis is done descriptively and inferentially. Descriptive analysis aims to see the increased mastery of concepts using gain scores. Furthermore, the gain score obtained is categorized according to the Sunal \& Emmett L Wright (2019) as shown in Table 2.

Table 2. Improved gain score category

\begin{tabular}{cc}
\hline Gain Score & Category \\
\hline$(\langle g\rangle) \leq 0,3$ & Low \\
$0,3<(\langle g\rangle) \leq 0,7$ & Moderate \\
$(\langle g\rangle)>0,7$ & High \\
\hline
\end{tabular}

The inferential analysis aimed to determine the differences between groups. The analysis used was the independent sample t-test assisted by SPSS 22.0 Program.

Before the test, the data must go through a prerequisite test, normality and homogeneity (Nurgiyantoro et al., 2015; Setyawarno, 2016). The overall level of significance is 0.05 , so if the value of $p<$ 0.05 can be concluded that there is an effect on the use of Science SSP based on discovery learning integrated by volcanic eruptions on students' concept mastery (Nurgiyantoro et al., 2015; Setyawarno, 2016). Besides that, Aberson (2019) and 
Warner (2013) define that the effect of independent variables on the dependent variables can be seen through Partial Etta Square's statistics. The value of Partial Etta Square ranges from $0-1$. A value of 0 indicates no relationship between the independent variable against the dependent variables, while a value of 1 indicates a strong relationship between the independent and dependent variables.

\section{RESULTS AND DISCUSSION Descriptive Analysis Result}

Concept mastery is measured using instruments in the form of multiple-choice questions consist of 35 questions given before and after learning activities in both experimental and control classes. Concept mastery measures the cognitive levels from $\mathrm{C} 1$ to $\mathrm{C} 6$ of bloom taxonomy. Here is one example of the problem used in the pretest and posttest, as shown in Table 3.

Table 3. Sample questions of concept mastery

\begin{tabular}{l} 
No Question \\
\hline $20 \quad$ Below are the phases of the magmatic eruption; \\
the untrue statement is... \\
A. destruction of lava plugs \\
B. lava growth \\
C. avalanche on a lava cliff \\
D. ash rain occurs \\
Regional Disaster Management Agency is an \\
institution that has the authority as one of the \\
central controls of disaster management \\
operations that exist at the regional, provincial, \\
and district levels. One of the tasks of that \\
institution is ... \\
A. cooperation \\
B. compile, establish, and inform disaster- \\
prone maps \\
C. conduct search and rescue for disaster \\
victims \\
D. community assistance in the context of \\
trauma healing
\end{tabular}

The students' answers in the control and the experiment class to the questions above are as shown in Table 4.

Table 4. Sample of Student's Answers

\begin{tabular}{lcccc}
\hline & \multicolumn{2}{c}{ No. 20 } & \multicolumn{2}{c}{ No. 25 } \\
\cline { 2 - 5 } & Pre & Post & Pre & Post \\
\hline Control Class & B & A & A & C \\
Experiment & A & D & C & B \\
Class & & & & \\
\hline
\end{tabular}

The raw data obtained in nominal data is then converted into interval data type with the Method of Successive Interval. The result of the gain score on the students' mastery of the concept as shown in Table 5.

Table 5. Gain score analysis result

\begin{tabular}{lcc}
\hline Aspect & $\begin{array}{c}\text { Experimental } \\
\text { Class }\end{array}$ & $\begin{array}{c}\text { Control } \\
\text { Class }\end{array}$ \\
\hline Pre Score & 27,62 & 26,19 \\
Post Score & 84,52 & 31,11 \\
Gain Score & 0,79 & 0,07 \\
Category & High & Low \\
\hline
\end{tabular}

Based on the results Table 5, it is known that the increases in the experiment class are higher than the control class. The experiment class gain score is 0.79 with a high category, while the control class gain score is 0.07 with a low category. Thus, it can be concluded that the experiment class obtained a higher gain score than the control class. This shows that the students' concept mastery using SSP based on discovery learning and volcanic eruptions was higher than the control class.

\section{Inferential Analysis Result}

The inferential analysis aimed to find out the differences between the group that uses Science SSP based on discovery learning and volcanic eruptions and the group that did not use Science SSP based on discovery learning and volcanic eruptions. Inferential analysis was done using an independent sample t-test in SPSS 22.0 program. Before conducting the test, a prerequisite test is required, namely the normality and homogeneity test. The prerequisite test results as shown in Table 6 .

Table 6. Normality test result

\begin{tabular}{lcc}
\hline \multicolumn{1}{c}{ Statistic } & $\begin{array}{c}\text { Experiment } \\
\text { Class }\end{array}$ & $\begin{array}{c}\text { Control } \\
\text { Class }\end{array}$ \\
\hline Shapiro - Wilk & 0,977 & 0,985 \\
Lilliefors & 0,200 & 0,200 \\
\hline
\end{tabular}

Normality Test using Shapiro - Wilk, and Lilliefors tests, as the sample in this study is less than 100 (Leech et al., 2005). Based on table 6 above, it is known that the statistical value of each test for both the 
experiment and the control class is more than 0.05, So, Green \& Salkind (2003) defines that data is normally distributed due to the statistical test value is more than 0.05 .

Table 7. Homogeneity test result

\begin{tabular}{lc}
\hline \multicolumn{1}{c}{ Statistic } & Result \\
\hline Levene's & 2,236 \\
Sig. & 0,140 \\
\hline
\end{tabular}

Based on table 7 above, it is known that the value of significance is 0.140 greater than the specified level of significance. Thus, it can be said that the data in the bound variables simultaneously is homogenous. After the two prerequisite tests are fulfilled, then the independent sample ttest is carried out. The Independent Sample t-test is a statistical analysis that compares two unpairs samples, the experiment, and the control class. The results of the Independent Sample t-test are as shown in Table 8.

Table 8. Independent sample t-test result

\begin{tabular}{lc}
\hline \multicolumn{2}{c}{ t-test for Equality of Means } \\
\hline Sig. (2 Tailed) & 0,000 \\
\hline
\end{tabular}

Based on table 8 above, it is known that the value of significance was 0.000 . This indicates an effect on the use of Science SSP based on discovery learning and volcanic eruptions on the students' concept mastery. The value of significance is less than the level of significance set, which is 0.05 . Also, the effect of independent to dependent variable can be seen through the Partial Etta Square statistics with the following results as shown in Table 9.

Table 9. Effect size test result

\begin{tabular}{ccc}
\hline \multicolumn{3}{c}{ Test of Between - Subject's Effects } \\
\hline Source & $\begin{array}{c}\text { Partial Etta } \\
\text { Square }\end{array}$ & Category \\
\hline Intercept & 0,924 & Very Strong \\
\hline
\end{tabular}

Based on the table 9, it is known that there are extreme differences in concept mastery variables over the use of Science SSP based on discovery learning and volcanic eruptions. These results are based on the theory put forward by Sugiyono (2012), which divides the categorization of Partial Etta Square into five categories, namely $0.00-0.199$ very weak, $0.20-$ 0.399 weak, $0.40-0.499$ medium, 0.60 0.799 strong, and $0.80-1,000$ very strong.

The use of effect size and statistics partial Etta square in hypothetical testing determines the scale of a study's effectiveness. Theoretically, Chen \& Peace (2013) and Cumming (2012) state that effect size shows the standardized difference between control and experiment scores. Researchers were interested in the differences and how significant the differences were between the control and the experiment. Effect Size is a standard unit compared between several different scales and studies with different sample sizes.

\section{Final Study}

Discovery learning syntax consists of 6 steps. The learning activities done by students are as shown in Table 10.

Table 10. Syntax and learning activities

\begin{tabular}{|c|c|}
\hline Syntax & Learning Activities \\
\hline $\begin{array}{l}\text { Stimulation } \\
\text { Stage }\end{array}$ & $\begin{array}{l}\text { Teachers begin teaching and } \\
\text { learning activities by asking } \\
\text { questions, suggesting reading books, } \\
\text { and other learning activities that lead } \\
\text { to problems. }\end{array}$ \\
\hline Problem & Teachers allow students to identify \\
\hline Statement & as many problems as possible related \\
\hline Stage & $\begin{array}{l}\text { to learning materials, then formulate } \\
\text { questions and hypotheses. }\end{array}$ \\
\hline Data & Students are allowed to conduct \\
\hline Collection & experiments or explorations to \\
\hline Stage & $\begin{array}{l}\text { answer questions and prove previous } \\
\text { hypotheses. }\end{array}$ \\
\hline Data & Students are allowed to process the \\
\hline Proces & data and information that has been \\
\hline Stage & obtained and then interpret the data. \\
\hline Verificatio & Students conduct $\quad$ careful \\
\hline n Stage & $\begin{array}{l}\text { examinations to prove whether the } \\
\text { hypothesis has been proven or not, } \\
\text { related to data processing results. }\end{array}$ \\
\hline $\begin{array}{l}\text { Generalizat } \\
\text { ion }\end{array}$ & $\begin{array}{l}\text { The concluding process can be used } \\
\text { as a learner's knowledge by taking } \\
\text { into account the verification results. }\end{array}$ \\
\hline
\end{tabular}

Learning with discovery models requires students to discover concepts and principles through their mental processes (Saehana et 
al., 2018). This causes students to be given the first-hand experience to be more active and more motivated in learning (Rusman, 2016). The learning syntax trains various cognitive domains of concept mastery, including remembering, understanding, applying, analyzing, evaluating, and creating (Karpen \& Welch, 2016; Radhmehr \& Drake, 2018; Wang et al., 2016). Also, discovery learning models help students improve their discussion skills (Ertikanto et al., 2018).

Concept mastery had been measured using multiple-choice questions consisted of 35 items given before and after learning. The concept mastery assessment results of the experiment class and the control class in the assessment before and after treatment are as shown in Figure 2.

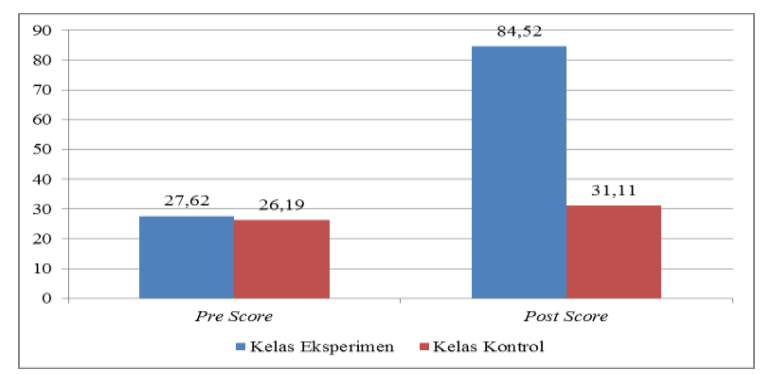

Figure 2. Concept mastery assessment graph

Based on the gain score analysis that has been done before and from the chart above, it is known that the increased mastery of experimental class concepts using Science SSP based on discovery learning integrated volcano eruption disaster is very significant compared to control classes that don't use the kind of Science SSP. Based on the MANOVA test results through Partial Etta Square intercept value in the test of between-subject effect, it is also known that Science SSP based on discovery learning integrated volcano eruption disaster provides a powerful effect with a value of 0.924 compared to the group of students who did not use the Science SSP.

The concept mastery measure was manifested in 35 multiple choice questions with cognitive levels C1 to C6. Students' concept mastery can be improved through learning that spurs thinking and intellectual skills. Factors that influence the improvement of concept mastery are conducive class conditions and the continuous training of challenging questions for students to encourage them to learn (van Alten et al., 2019).

Research conducted by Syar (2017) found that teaching materials can improve the students' concept of mastery. Experiment classes that obtained material from handouts experienced a significant increase in scores compared to control classes that did not use handouts. This shows handouts, which is a part of Science SSP, are influential in improving the students' mastery concepts. The use of handouts as natural science references can be applied to other materials adapted to learning materials' characteristics. This aims to improve the students' concept of mastery.

Rahayu (2017) mentions that the discovery-based worksheet provides students with the opportunity to think independently in planning research procedures, determining research variables, and formulating hypotheses. This is certainly in line with students' cognitive aspects, thus encouraging students to master the concept and achieve the completeness indicators. As a development, handouts and student worksheets can be packaged in mobile apps, as it is believed to develop learning into more meaningful and interactive (Hirsh-pasek et al., 2015).

One of the activities carried out in learning is a simulation. Simulation activities were carried out at the last meeting related to volcanic eruption disaster mitigation simulation. Students are doing an unplanned simulation, wherein in the middle of the learning activity, an alarm goes on, indicating that an eruption occurred. Simulation activities also have a role in the mastery of concepts. Stave et al. (2015) mentioned that students' understanding improved significantly after conducting simulation activities. 
Discovery-based natural science learning is the demand for students' activities to train to improve cognitive, affective, or psychomotor aspects indirectly. The syntax in the discovery learning model requires students to be actively involved in each learning activity. Students listen to the teacher's explanations and explore their understanding and discover knowledge independently (Limbong et al., 2019).

Kumullah et al. (2018) found that one factor driving students' ability to understand the learning concept is discussion and practicum activities. This is because students are given the freedom to solve their problems through group discussions. Teachers only act as facilitators who respond to the concepts that have been invented by students themselves. Moreover, Marlina et al. (2017) mention that daily life phenomena can stimulate students' thinking skills in problem-solving to gain a deeper understanding.

Although the increase in students' concept mastery in the experiment class was significant, some students did not meet a significant increase. This may be caused by the inability of several students to construct knowledge properly. However, their score is increased as a result of learning, following the opinion of Rahmawati et al. (2016), which suggests that this may be due to differences in the natural abilities of different students in constructing concepts. Also, learning by the usual method of lectures can affect that ability.

Concept mastery is the students' ability to re-uncover the material that has been taught. The assessment of the concept mastery carried out in this study is through tests. This is following Dong's (2020) opinion, which found that the most plausible concept mastery assessments were through the assessment of learning outcomes using a specific range of grades on a test, then assessed by educators. A less reasonable assessment is an assessment made between friends because it doubts its objectivity.
Based on this research results, Science SSP based on discovery learning and volcanic eruptions effectively increased students' concept mastery with very significant results compared to students who did not use that Science SSP. This was because the discovery learning model equips students to find their knowledge and concepts, so the material taught will undoubtedly be essential and improve the concept's mastery. In line with the research results conducted by Noviyani et al. (2017) and Wati et al. (2018), the selection of the right learning model can facilitate students to improve their mastery of concepts. Supporting this, Nevid \& Gordon (2018) mentions that integrated science produces benefits for learning, especially on cognitive mastery performance in varying levels of bloom taxonomy. In this case, the study group's average post score with the discovery learning model was much higher than the group of students who used conventional learning models.

However, concept mastery is not enough to generalize that students are experts (Winch, 2016). Further research is needed with different bound variables to assess natural science's successful integration with various other types of disasters that become natural science phenomena. This was supported by Norton \& Gibson (2019) and Pandey (2018), who mentioned that concept mastery was the beginning of the creation of a resilient society. Integration in the learning process also contributes to a broader understanding of the scale of disaster prevention.

\section{CONCLUSION}

Based on the research, Science SSP based on discovery learning and volcanic eruptions affected students' concept mastery. The descriptive analysis results showed that students who used Science SSP based on discovery learning and volcanic eruptions obtained high mastery scores with a gain score of 0.79 . The students who did not use Science SSP increased their concept 
mastery with a gain score of 0.07 . The independent sample t-test results showed that Sig. 2 Tailed value of 0,000 or less than the significance level was established. It showed that the Science SSP based on discovery learning and volcanic eruptions affected student's concept mastery. The effect size test showed extreme differences in concept mastery variables over the use of Science SSP based on discovery learning and volcanic eruptions with a Partial Etta Square's value of 0.924 .

\section{ACKNOWLEDGEMENT}

We thank to the "Directorate of research and community services, deputy of research and development empowerment, the ministry of research and technology/ National research and innovation agency" for the funding that has been given to the completion of this research.

\section{AUTHOR CONTRIBUTIONS}

RAT and P collected and analysed data. $\mathrm{P}$ display data. $\mathrm{S}$ prepared research design. RAT prepared literature related to research. RAT, P and S wrote the manuscript.

\section{REFERENCES}

Aberson, C. L. (2019). Applied power analysis for the behavioral sciences (2nd Editio). New York: Routledge.

Afriana, J., Permanasari, A., \& Fitriani, A. (2016). Project based learning integrated to STEM to enhance elementary school's students scientific literacy. Jurnal Pendidikan IPA Indonesia, 5(2), 261-267. https://doi.org/10.15294/jpii.v5i2.5493

Almukarramah, Fadhillah, \& Sudrajat, A. (2013). Integrasi konsep kebencanaan dalam implementasi kurikulum 2013 di sekolah dasar. Jurnal Pendidikan Dasar, 10(2), 118-130. https://doi.org/doi.org/10.21009/JPD.0 102.12

Amri, M. R., Yulianti, G., Yunus, R., Wiguna, S., Adi, A. W., Ichwana, A. N., Randongkir, R. E., \& Septian, R. T.
(2016). Risiko bencana Indonesia (R. Jati (ed.)). Jakarta: Badan Nasional Penanggulangan Bencana.

Anazifa, R. D., \& Djukri. (2017). Projectbased learning and problem-based learning: Are they effective to improve students' thinking skills? Jurnal Pendidikan IPA Indonesia, 6(2), 346355.

https://doi.org/10.15294/jpii.v6i2.1110 0

Arnold, J. C. (2018). An integrated model of decision-making in health contexts: The role of science education in health education. International Journal of Science Education, 4(5), 1-19. https://doi.org/10.1080/09500693.2018. 1434721

Azwar, S. (2015). Metode penelitian. Yogyakarta: Pustaka Pelajar.

Belton, D. J. (2016). Teaching process simulation using video-enhanced and discovery/inquiry-based learning: Methodology and analysis within a theoretical framework for skill acquisition. Journal Education for Chemical Engineers, 17(2002), 54-64. https://doi.org/10.1016/j.ece.2016.08.0 03

Chen, D. G., \& Peace, K. E. (2013). Applied meta-analysis with $R$. Boca Raton: CRC Press.

Cumming, G. (2012). Understanding the new statistic effect sizes: Confidence, intervals, and meta-analysis. New York: Routledge.

Djamarah, S. B., \& Zain, A. (2013). Strategi belajar mengajar. Jakarta: Rineka Cipta.

Dong, M. (2020). Structural relationship between learners' perceptions of a test, learning practices, and learning outcomes: A study on the washback mechanism of a high-stakes test. Journal of Studies in Educational Evaluation, 64(March 2020), 100824. https://doi.org/10.1016/j.stueduc.2019. 100824

Ertikanto, C., Rosidin, U., Distrik, I. W., 
Yuberti, \& Rahayu, T. (2018). Comparison of mathematical representation skill and science learning result in classes with problembased and discovery learning model. Jurnal Pendidikan IPA Indonesia, 7(1), 106-113.

https://doi.org/10.15294/jpii.v6i2.9512

Green, S. B., \& Salkind, N. J. (2003). Using SPSS for windows and macintosh: Analyzing and understanding data (3rd Editio). Upper Saddle River: Prentice Hall Inc.

Großmann, N., \& Wilde, M. (2019). Experimentation in biology lessons: Guided discovery through incremental scaffolds. International Journal of Science Education, 4(6), 759-781. https://doi.org/10.1080/09500693.2019. 1579392

Guzey, S. S., \& Ring-whalen, E. A. (2018). Negotiating science and engineering: An exploratory case study of a reformminded science teacher. International Journal of Science Education, 40(7), 723-741.

https://doi.org/10.1080/09500693.2018. 1445310

Hairida. (2016). The effectiveness using inquiry based natural science module with authentic assesment to improve the critical thinking and inquiry skills of junior high school students. Jurnal Pendidikan IPA Indonesia, 5(2), 209215.

https://doi.org/10.15294/jpii.v5i2.7681

Hanafi. (2016). The effect of discovery learning method application on increasing students' listening outcome and social attitude. Jurnal Dinamika Ilmu, 16(2), 291-306.

Hartati, T. (2016). PCK (pedagogical content knowledge) bagi mahasiswa S2 pendidikan dasar dalam rangka implementasi kurikulum 2013. Jurnal Pendidikan Sains Sosial dan Kemanusiaan, 9(1), 173-182.

Hayudityas, B. (2020). Pentingnya penerapan pendidikan mitigasi bencana di sekolah untuk mengetahui kesiapsiagaan peserta didik. Jurnal Edukasi Nonformal, 1(2), 94-102.

Hidayati, D. (2012). Striving to reduce disaster risk: Vulnerable communities with low levels of preparedness in Indonesia. Journal of Disaster Research, 7(1), 75-82.

Hirsh-pasek, K., Zosh, J. M., Golinkoff, R. M., Gray, J. H., Robb, M. B., \& Kaufman, J. (2015). Putting education in "educational" apps: Lessons from the science of learning. Journal of Psychological Science in the Public Interest, 16(1), 3-34. https://doi.org/10.1177/1529100615569 721

Karpen, S. C., \& Welch, A. C. (2016). Assessing the inter-rater reliability and accuracy of pharmacy faculty's bloom's taxonomy classifications. Journal of Currents in Pharmacy Teaching and Learning, 8(6), 885-888. https://doi.org/https://doi.org/10.1016/j. cpt1.2016.08.003

Kenny, C. (2012). Disaster risk reduction in developing countries: Cost, benefits and institutions. Journal Compilation of Disasters, 36(4), 559-588.

Koehler, M. J., \& Mishra, P. (2009). What is technological pedagogical content knowledge? Journal Contemporary Issues in Technology and Teacher Education, 9(1), 60-70.

Kumullah, R., Djatmika, E. T., \& Yuliati, L. (2018). Kemampuan berpikir kritis dan penguasaan konsep siswa dengan problem based learning pada materi sifat cahaya. Jurnal Pendidikan: Teori, Penelitian, dan Pengembangan, 3(12), 1583-1586.

Kusmawati, A. (2017). Pengembangan SSP biologi domain kreativitas untuk meningkatkan karakter kreatif, tanggung jawab, dan prestasi belajar siswa. Jurnal Inovasi Pendidikan IPA, $3(1), 12-21$.

Labibah, U. N., Wilujeng, I., Sulaiman, S., \& Rahmawati, L. (2019). Android- 
based physics learning media integrated landslide disaster. Jurnal Ilmiah Pendidikan Fisika Al Biruni, $8(2)$, 233-240. https://doi.org/10.24042/jipfalbiruni.v0 i 0.4695

Lee, C. J., \& Kim, C. M. (2014). An implementation study of a TPACK based instructional design model in a technology integration course. Journal of Education Technology Research Development, 62, 437-460. https://doi.org/10.1007/s11423-0149335-8

Leech, N. L., Barrett, K. C., \& Morgan, G. A. (2005). SPSS for intermediate statistics (2nd Edition (ed.)). Lawrence Erlbaum Associates.

Limbong, C., Rohadi, N., \& Hamdani, D. (2019). Meningkatkan motivasi belajar dan penguasaan konsep dengan model pembelajaran siklus belajar tipe $5 \mathrm{E}$ di kelas X IPA 3 SMA N 9 kota Bengkulu. Jurnal Kumparan Fisika, 2(1), 33-40. https://doi.org/e-ISSN: 2655-1403

Lin, T. C., Tsai, C. Ch., Chai, C. S., \& Lee, M. H. (2013). Identifying science teachers perceptions of technological pedagogical and content knowledge (TPACK). Journal Science Education Technology, 22, 325-336. https://doi.org/10.1007/s10956-0129396-6

Marlina, Utaya, S., \& Yuliati, L. (2017). Pengaruh authentic problem based learning (APBL) terhadap penguasaan konsep IPA siswa kelas IV sekolah dasar. Jurnal Pendidikan: Teori, Penelitian, dan Pengembangan, 2(11), 1509-1514.

Mukti, Y. P., Masykuri, M., Sunarno, W., Rosyida, U. N., Jamain, Z., \& Dananjoyo, M. D. (2020). Exploring the impact of project-based learning and discovery learning to the students , learning outcomes : Reviewed from the analytical skills. Jurnal Ilmiah Pendidikan Fisika Al Biruni, 9(1), 121-
131.

https://doi.org/10.24042/jipfalbiruni.v9 i1.4561

Nevid, J. S., \& Gordon, A. J. (2018). Integrated learning systems: Is there a learning benefit? Journal Teaching of Psychology, 45(4), 340-345. https://doi.org/10.1177/0098628318796 920

Norton, J., \& Gibson, T. D. (2019). Introduction to disaster prevention: Doing it differently by rethinking the nature of knowledge and learning. Disaster Prevention and Management: An International Journal, 28(1), 2-5. https://doi.org/10.1108/DPM-02-2019323

Noviyani, M., Kusairi, S., \& Amin, M. (2017). Penguasaan konsep dan kemampuan berargumentasi siswa SMP pada pembelajaran IPA dengan inkuiri berbasis argumen. Jurnal Pendidikan: Teori, Penelitian, Dan Pengembangan, 2(7), 974-978.

Nurgiyantoro, B., Gunawan, \& Marzuki. (2015). Statistik terapan untuk penelitian ilmu sosial. Yogyakarta: Gadjah Mada University Press.

Pandey, C. L. (2018). Making communities disaster resilient: Challenges and prospects for community engagement in Nepal. Disaster Prevention and Management: An International Journal, 28(1), 106-118.

Perkasa, M., \& Aznam, N. (2016). Pengembangan SSP kimia berbasis pendidikan berkelanjutan untuk meningkatkan literasi kimia dan kesadaran terhadap lingkungan. Jurnal Inovasi Pendidikan IPA, 2(1), 46-57.

Prasetyo, Z. K. (2011). Pengembangan perangkat pembelajaran sains terpadu untuk meningkatkan kognitif, keterampilan proses, kreativitas, serta menerapkan konsep ilmiah peserta didik SMP.

Puspitasari, A., \& Handziko, R. C. (2018). Pengembangan LKPD mobile learning guided discovery untuk meningkatkan 
penguasaan kompetensi dasar ekosistem kurikulum 2013. Jurnal Inovasi Pendidikan IPA, 4(1), 83-97. https://doi.org/http://dx.doi.org/10.2183 1/jipi.v4i1.17003

Radhmehr, F., \& Drake, M. (2018). An assesment based model for exploring the solving of mathematical problems: Utilizing revised bloom's taxonomy and facets of metacognition. Journal of Studies in Educational Evaluation, 59, 41-51.

https://doi.org/https://doi.org/10.1016/j. stueduc.2018.02.004

Rahayu, N. (2017). Pengaruh pembelajaran dengan pendekatan inquiry terhadap penguasaan konsep dan scientific skill materi sistem pencernaan. Jurnal Inovasi Pendidikan IPA, 3(1), 70-77.

Rahmawati, I., Hidayat, A., \& Rahayu, S. (2016). Penguasaan konsep IPA siswa SMP pada materi tekanan pada zat cair dan aplikasinya. Jurnal Pendidikan Sains, 4(3), 102-112.

Riezqia, R., Rahardini, B., Putu, I. G., \& Wilujeng, I. (2017). The effect of science learning integrated with local potential to improve science process skills. The 4th International Conference on Research, Implementation, and Education of Mathematics and Science (4th ICRIEMS), $\quad 080008$ (August). https://doi.org/10.1063/1.4995192

Rusman. (2016). Model-model pembelajaran: Mengembangan profesionalisme guru. Depok: PT Raja Grafindo Persada.

Sadeka, S., Mohamad, M. S., \& Sarkar, M. S. K. (2020). Disaster experiences and preparedness of the orang asli families in tasik chini of Malaysia: A conceptual framework towards building disaster resilient community. Journal of Progress in Disaster Science, 6. https://doi.org/https://doi.org/10.1016/j. pdisas.2020.100070

Saehana, S., Rosnaeni, \& Muslimin. (2018).
Perbandingan keterampilan proses sains antara kelompok siswa yang diajar dengan model POE dan model discovery. Jurnal Pendidikan Fisika, 6(1), 43-53.

Sangkala, M. S., \& Gerdtz, M. F. (2018). Disaster preparedness and learning needs among community health nurse coordinators in South Sulawesi Indonesia. Journal of Australasian Emergency Care, 21(1), 23-30. https://doi.org/https://doi.org/10.1016/j. auec.2017.11.002

Schijndel, T. J. P. Van, Jansen, B. R. J., \& Raijmakers, M. E. J. (2018). Do individual differences in children's curiosity relate to their inquiry-based learning? International Journal of Science Education, 40(9), 1-20. https://doi.org/10.1080/09500693.2018. 1460772

Setiawan, B., Innatesari, D. K., Sabtiawan, W. B., \& Sudarmin. (2017). The development of local wisdom based natural science module to improve science literation of students. Jurnal Pendidikan IPA Indonesia, 6(1), 4954.

https://doi.org/10.15294/jpii.v6i1.9595

Setiawati, I. K., Rusilowati, A., \& Khumaedi. (2013). Pembuatan buku cerita IPA yang mengintegrasikan materi kebencanaan alam untuk meningkatkan literasi membaca dan pembentukan karakter. Jurnal Pendidikan IPA Indonesia, 2(2), 129135.

Setyawarno, D. (2016). Panduan statistik terapan untuk penelitian pendidikan. Yogyakarta: FMIPA UNY.

Stave, K. A., Beck, A., \& Galvan, C. (2015). Improving learners' understanding of environmental accumulations through simulation. Journal of Simulation \& Gaming, 46(3-4), 270-292. https://doi.org/10.1177/1046878114531 764

Sugiyono. (2012). Metode penelitian pendidikan pendekatan kuantitatif, 
kualitatif, dan $R \& D$. Bandung: Alfabeta.

Sugiyono. (2015). Metode penelitian dan pengembangan (S. Y. Suryandari (ed.)). Bandung: Alfabeta.

Sunal, D. W., \& Emmett L Wright. (2019). Physics teaching and learning: Challenging the paradigm. New Castle: Information Age Publishing Inc.

Syaban, M. F., \& Wilujeng, I. (2016). Pengembangan SSP zat dan energi berbasis keunggulan lokal untuk meningkatkan literasi sains dan kepedulian lingkungan. Jurnal Inovasi Pendidikan IPA, 2(1), 66-75. https://doi.org/http://dx.doi.org/10.2183 1/jipi.v2i1.8369

Syah, M. (2013). Psikologi pendidikan dengan pendekatan baru. Bandung: PT Remaja Rosdakarya.

Syar, N. I. (2017). Penggunaan bahan ajar IPA terpadu dengan tema cuaca untuk meningkatkan penguasaan konsep siswa. Jurnal Edusains, 9(1), 34-40.

Tahmidaten, L., \& Krismanto, W. (2019). Implementasi pendidikan kebencanaan di Indonesia (sebuah studi pustaka tentang problematika dan solusinya). Lectura: Jurnal Pendidikan, 10(2), 136-154.

Turkka, J., Haatainen, O., \& Aksela, M. (2017). Integrating art into science education: A survey of science teachers' practices. International Journal of Science Education, 39(10), 1403-1419.

https://doi.org/10.1080/09500693.2017. 1333656

Tyas, R. A., Wilujeng, I., \& Suyanta, S. (2020). Pengaruh pembelajaran IPA berbasis discovery learning terintegrasi jajanan lokal daerah terhadap keterampilan proses sains. Jurnal Inovasi Pendidikan IPA, 6(1), 114 125.

https://doi.org/https://doi.org/10.21831/ jipi.v6i1.28459

van Alten, D. C. D., Phielix, C., Janssen, J.,
\& Kester, L. (2019). Effects of flipping the classroom on learning outcomes and satisfaction: A meta analysis. Journal of Educational Research Review, 28(November), 1-18. https://doi.org/10.1016/j.edurev.2019.0 5.003

Verstappen, H. T. (2013). Garis besar geomorfologi Indonesia (Suratman (ed.)). Yogyakarta: Gadjah Mada University Press.

Wang, J., Wei, W., Ding, L., \& Li, J. (2016). Method for analyzing the knowledge collaboration effect of R\&D project teams based on bloom's taxonomy. Journal of Computers \& Industrial Engineering, 103, 158-167. https://doi.org/https://doi.org/10.1016/j. cie. 2016.11 .010

Warner, R. M. (2013). Applied statistics: From bivariate through multivariate techniques. London: Sage Publication.

Wati, A., Susilo, H., \& Sutopo. (2018). Pengaruh pembelajaran inkuiri terbimbing berbantuan jurnal belajar terhadap penguasaan konsep IPA siswa. Jurnal Pendidikan: Teori, Penelitian, dan Pengembangan, 3(1), 129-133.

Widjanarko, M., \& Minnafiah, U. (2018). Pengaruh pendidikan bencana pada perilaku kesiapsiagaan siswa. Jurnal Ecopsy, 5(17), 1-7.

Winch, C. (2015). Professional education, know-how and conceptual ability: The role of education in the attainment of concept mastery in professional work. Theory and Research in Education, 14(1), 45-62.

Yahaya, J. M., Nurulazam, A., \& Karpudewan, M. (2016). College students' attitudes towards sexually themed science content: A socioscientific issues approach to resolution. International Journal of Science Education, 38(7), 1174-1196. https://doi.org/10.1080/09500693.2016. 1174349 